\title{
Analisis Peran dan Fungsi Public Relations di Lembaga Pendidikan Islam
}

\author{
Analysis of the Role and Function of Public Relations at Islamic Education \\ Institutions
}

\author{
Pasha Syahritsa Maulana ${ }^{1}$, Subhan Afifi² \\ 1,2 Program Studi Ilmu Komunikasi, Universitas Islam Indonesia, Sleman \\ Yogyakarta, Indonesia
}

\section{Author's email: \\ ${ }^{1} 17321063 @$ students.uii.ac.id \\ 2 subhan.afifi@ac.id* \\ *Corresponding author}

\begin{abstract}
Islamic Education Institutions are places where the educational process takes place with the aim of changing individual behavior in a better direction through interaction with the surrounding environment, based on Islamic values. In addition to carrying out the teaching and learning process, the Islamic Education Institute manages public relations activities in the form of communication management with the internal public and external public. This study aims to determine the role and function of public relations in Islamic Educational Institutions. The research method used is a case study which is one type of qualitative research method with an interpretive paradigm. The case study was conducted at SDIT in Sleman, Yogyakarta Special Region. The results of this study indicate that schools carry out the roles and functions of public relations management in the form of internal relations and external relations. Internal relations are carried out in various employee relations programs such as providing work motivation and achievement, education and training, as well as special events that strengthen the intimacy of teachers and employees. External relations are run through community relations and government relations programs. Community relations are carried out by establishing good relations with the surrounding community, while government relations are carried out with district government agencies, especially the Education Service.
\end{abstract}

Keywords: public relations, Islamic educational institution, Islamic primary school.

Lembaga Pendidikan Islam merupakan tempat berlangsungnya proses pendidikan dengan tujuan mengubah tingkah laku individu ke arah yang lebih baik melalui interaksi dengan lingkungan sekitar, berdasarkan nilai-nilai Islam. Selain menjalankan proses belajar mengajar, Lembaga Pendidikan Islam mengelola kegiatan public relations berupa manajemen komunikasi dengan publik internal dan publik eksternal. Penelitian ini bertujuan mengetahui peran dan fungsi public relations Lembaga Pendidikan Islam. Metode penelitian yang digunakan adalah studi kasus yang merupakan salah satu jenis metode penelitian kualititatif dengan paradigma interpretif. Studi kasus dilaksanakan di SDIT di Sleman, Daerah Istimewa Yogyakarta. Hasil penelitian ini menunjukkan sekolah menjalankan peran dan fungsi manajemen public relations berupa internal relations dan external relations. Internal relations dijalankan dalam berbagai program employee relations seperti pemberian motivasi kerja dan prestasi, pendidikan dan pelatihan, serta acara-acara khusus yang menguatkan keakraban guru dan karyawan. External relations dijalankan melalui program community relations dan government relations. Community relations dijalankan dengan menjalin hubungan baik dengan masyarakat sekitar, sedangkan government relations dijalankan dengan instansi pemerintah kabupaten, khususnya Dinas Pendidikan. 


\section{PENDAHULUAN}

Lembaga Pendidikan Islam merupakan tempat berlangsungnya proses pendidikan dengan tujuan mengubah tingkah laku individu ke arah yang lebih baik melalui interaksi dengan lingkungan sekitar, berdasarkan nilai-nilai ajaran Islam.

$$
\text { Selain menjalankan proses }
$$

belajar mengajar, secara umum

Lembaga Pendidikan mengelola kegiatan public relations berupa manajemen komunikasi dengan para pemangku kepentingan (stakeholders) yaitu publik internal dan publik eksternal. Menurut James R. Emshoff (dalam Kasali, 1994), stakeholders merupakan semua kelompok yang tercakup dalam ranah internal dan eksternal yang mempunyai pengaruh dalam menentukan kesuksesan lembaga.

Beberapa contoh masalah di dunia pendidikan yang pernah terjadi terkait publik internal misalnya aksi mogok kerja 9 guru sebuah sekolah swasta di Jember yang memprotes kepemimpinan Kepala Sekolah yang bertindak sewenangwenang, bahkan hingga melakukan tindakan kekerasan (Mulyono, 2019). Terdapat juga aksi mogok mengajar dan penutupan pagar sekolah oleh para guru sebuah SD di Kabupaten Sarolangun pada 2020 karena memprotes kepemimpinan Kepala Sekolah. (Jambitribunnews, 2020)

Beberapa contoh kasus tersebut menunjukkan terdapat dinamika komunikasi sekolah dengan publik internal dan eksternalnya. Beberapa persoalan yang muncul diantaranya disebabkan oleh masalah kepemimpinan dan manajemen sekolah, sistem organisasi dan keterbukaan, pola komunikasi manajemen sekolah-guru-orangtua, hingga masalah yang terkait dengan pemenuhan hak-hak guru yang berhubungan dengan implementasi kebijakan pemerintah.
Dalam konteks ini, peran dan fungsi public relations di lembaga pendidikan menjadi sangat penting.

J.E.Grunig dan T.Hunt mendefinisikan Public relations secara singkat, yaitu manajemen dari komunikasi antara lembaga dan publik-publiknya (Suwatno, 2018). Publik terbagi menjadi dua, yaitu internal dan eksternal. Publik internal adalah publik yang tergabung dalam lembaga, dan penerapannya disebut Internal Public relations, sedangkan publik eksternal adalah publik yang berada di luar lembaga, dan disebut External Public relations.

Menurut Widjaja (Mayasari \& Angguntiara, 2018), turunan dari penerapan internal public relations adalah employee relations (kepegawaian secara formal), human relations (kepegawaian secara informal), labour relations (hubungan direksi/manajer dan serikat buruh), dan stockholder relations (hubungan lembaga dan pemegang saham) Menurut Effendy, hubungan eksternal adalah hubungan yang dibangun antara lembaga dan publik luarnya (masyarakat, pemerintah, konsumen, media, dan lain-lain), berdasarkan pengertian dan kepercayaan, melalui komunikasi dua arah untuk membina hubungan baik, demi tujuan dan kepentingan bersama (Siwala, 2017).

Turunan external public relations meliputi community relations, government relations, customer relations, media relations, dan lain-lain. Namun, sebelum mengurus hal-hal yang berkaitan dengan publik eksternal, seorang praktisi public relations harus memprioritaskan hal-hal yang berkaitan dengan publik internal. Ini karena publik internal merupakan satu kesatuan yang menjadi penggerak dari sebuah lembaga (Choerunnisa \& Yuniarti, 2015).

Peran dan fungsi public relations terhadap internal lembaga lebih 
difokuskan pada pembentukan citra baik dimata stakeholders internal, seperti manajemen, pegawai, dan dewan pengawas. Di samping meningkatkan kesetiaan, public relations juga membuat perencanaan dalam menciptakan lingkungan kerja yang nyaman, baik saat kondisi normal maupun terjadi perubahan (Wasesa, 2006). Public Relations sebagai salah satu elemen komunikasi pemasaran diperlukan dan diimplementasikan berbagai bentuk lembaga dan perusahaan dalam berbagai skalanya (Utomo \& Afifi, 2004).

Internal public relations dapat dilaksanakan dengan melakukan komunikasi dalam menyampaikan perkembangan lembaga. Ini dilakukan untuk memperoleh dukungan. Untuk mendukung implementasinya, sarana yang digunakan harus dapat mengirim informasi ke seluruh stakeholder internal (Choerunnisa \& Yuniarti, 2015).

Beberapa penelitian tentang public relations di lembaga pendidikan, telah dilakukan oleh para peneliti sebelumnya, dengan fokus penelitian yang berbedabeda. Cahyaningrum (2018) pernah meneliti tentang strategi public relations dalam mengembangkan citra lembaga pendidikan. Mardiansyah (2011) meneliti strategi employee relations di sebuah lembaga pendidikan terkait dengan penanganan kasus korupsi.

Nafi'ah (2018) meneliti tentang strategi public relations SDIT dalam membangun citra lembaga. Selanjutnya, Fitri (2018) meneliti tentang cyber public relations dunia pendidikan. Hartini (2016) meneliti tentang strategi community relations lembaga pendidikan. Penelitian tersebut mendeskripsikan tentang program community relations sekolah yang dirancang berdasarkan kondisi sosial dari komunitas tempat sekolah tersebut berlokasi, termasuk mengelola krisis terkait dengan keluhan dari warga sekitar. Afifi dan Hariyanti (2021) meneliti tentang Relationship Marketing Communication yang diimplementasikan sekolah selama masa Pandemi Covid-19.

Penelitian ini bertujuan untuk menganalisis peran dan fungsi public relations di lembaga pendidikan Islam. Riset difokuskan pada bagaimana peran dan fungsi public relations dijalankan oleh Lembaga Pendidikan Islam, baik secara internal maupun eksternal, serta hambatan-hambatan yang ditemui dalam implementasi tersebut.

Kebaruan (novelty) yang ditawarkan adalah konteks penelitian yang dilaksanakan pada sekolah Islam yang berada di wilayah pedesaan, dan masih dalam tahap pengembangan. Sejauh ini, penelitian-penelitian terdahulu lebih banyak dilakukan pada konteks lembaga pendidikan di daerah perkotaan dan telah mapan secara institusi. Penelitian ini diharapkan dapat mengisi kekosongan kajian (research gap) yang belum dilakukan peneliti sebelumnya.

\section{KERANGKA TEORI}

Kegiatan public relations pada hakikatnya adalah sebuah proses komunikasi. Menurut Ivy dan Baklund (Mulyana, 2010), komunikasi adalah proses yang dinamis dan terus berlangsung dalam mengirim dan menerima pesan untuk berbagi makna. Menurut Mulyana, komunikasi public relations adalah komunikasi yang dilakukan secara sengaja (Sanityastuti, Pratiwi, \& Wijayanti, 2009).

Definisi kerja IPRA (International Public relations Association) melalui $A$ Model For Public Relations Professional Practice, Rex F. Harlow (1994; seperti dikutip Rumanti, 2002) menyebutkan fungsi manajemen yang memberikan dukungan pada pembinaan, merawat komunikasi termasuk pengertian dan penerimaan antara lembaga dan publik yang membutuhkan partisipasi dari 
manajemen dalam permasalahan, mendukung melayani penerangan dan respon terkait dengan opini publik, membantu manajemen melakukan dan memanfaatkan perubahan dengan tepat, berperan sebagai pengingat dalam membantu mendahului kecenderungan, serta memanfaatkan riset dan teknik komunikasi sebagai sarana utama.

Sasaran utama public relations sekolah adalah meningkatkan literasi tentang isu-isu pendidikan, membangun relasi dengan konstituen kunci, memperoleh penerimaan dan partisipasi publik terhadap pendidikan, dan meningkatkan citra sekolah (Cutlip, Center, \& Broom, 2007).

Pertimbangan yang perlu diperhatikan dalam menempatkan public relations di organisasi menyangkut tipe manajemen, harapan keberadaannya, alasan dibutuhkannya, tugasnya, hubungan dengan organisasi, tersedianya praktisi, dan makna keberadaan dan kesadarannya terhadap lingkungan (Rumanti, 2002).

Ada lima tugas pokok public relations sehari-hari, yaitu melaksanakan penyebaran informasi, melakukan evaluasi tanggapan masyarakat, mempertahankan citra lembaga, bersikap jujur dan terbuka pada publik, melakukan komunikasi dua arah (Rumanti, 2002).

Menurut Bloom \& Smith dan Bloom \& Dozel, praktisi public relations menjalankan dua peran, yakni manajer komunikasi dan teknisi komunikasi. Manajer komunikasi terbagi menjadi tiga, yaitu penyedia solusi ahli (meneliti isu dan membuat program), fasilitator komunikasi (mediator dan penerjemah), dan fasilitator pemecah masalah (penasihat dalam perencanaan dan implementasi rencana public relations). Teknisi komunikasi yang bertanggung jawab atas program public relations menyangkut teknis seperti membuat press release, event, konten situs web (Suwatno, 2018).
Dalam pembentukan program public relations, terdapat alur yang terus berkelanjutan, yaitu mencari titik permasalahan termasuk mencari data dan analisis, membuat strategi dan program, melaksanakan strategi dan program yang telah dibuat, dan melakukan evaluasi untuk mendapatkan bahan dalam merancang strategi selanjutnya (Cutlip, Center \& Broom, 2005).

Dalam menjalin relasinya, public relations dihadapkan pada berbagai karakter publik. Secara garis besar, dapat dibedakan ke dalam public relations internal dan eksternal. Hubungan dengan publik internal disebut sebagai internal relations, sedangkan yang eksternal disebut sebagai external relations.

Internal public relations adalah program komunikasi yang melibatkan publik yang tergabung dalam lembaga, yang secara fungsional memiliki tugas dan hak serta kewajiban tertentu (Sanityastuti, Pratiwi, \& Wijayanti, 2009). Employee relations adalah turunan dari internal relations. Menurut Widjaja (2010), employee relations berfungsi merawat hubungan antara manajemen dan karyawan dalam kepegawaian secara formal, menyangkut gaji, pangkat, mutasi, pensiun, pemberhentian, dan lain-lain (Mayasari \& Angguntiara, 2018).

Komunitas adalah salah satu publik terpenting dari sebuah lembaga. Merawat hubungan baik dengan komunitas membutuhkan partisipasi manajemen dan karyawan, serta kontribusi pada organisasi dan kegiatan lokal. Disamping itu, lembaga dapat berkomunikasi dengan komunitas melalui publikasi-publikasi lembaga atau melalui pertemuan dengan pemimpin masyarakat. Community relations melibatkan interaksi tatap muka dalam kegiatannya. Penyelesaian kendala community relations dapat mengikuti alur riset, tujuan, pemrograman, dan evaluasi (Hendrix \& Heyes, 2010). 
Tujuan dilakukannya kegiatan community relations, yaitu (1) menyalurkan informasi mengenai lembaga, (2) menyelesaikan kesalahpahaman, menerima kritik, serta membentuk dukungan dan opini yang baik, (3) mendapatkan dukungan secara resmi yang akan berpengaruh pada iklim komunitas, (4) memahami sikap, pengetahuan, dan harapan komunitas, (5) Memberikan dukungan sarana kesehatan, pendidikan, rekreasi, dan budaya, (6) Mendapatkan pengakuan yang baik dari pemerintah lokal, (7) Memberi dukungan pengembangan ekonomi sekitar dengan mengkonsumsi barang-barang dari wilayah sekitar (Yudarwati, 2004).

Hubungan publik internal lainnya adalah government relations yang berfokus pada hubungan dengan pemerintah, regulator, legislatif, dan aparat (Suwatno, 2018). Menurut Kasali, tujuan dari government relations, yaitu: (1) meningkatkan frekuensi komunikasi terhadap pejabat pemerintah dan lembaga tinggi negara, (2) memantau pengambilan keputusan dan peraturan di ranah yang berpengaruh pada bidang usaha, (3) meningkatkan partisipasi rakyat di setiap lapisan pemerintah, (4) berpartisipasi pada undang-undang yang berdampak pada ekonomi rakyat dan pelaksanaanya, (5) meningkatkan pengertian dan kesadaran para pengambil keputusan.

Berbagai aktivitas dapat dikembangkan untuk menjalin hubungan yang baik dengan pemerintah setempat, mulai dari berpartisipasi secara aktif pada berbagai agenda pemerintah yang relevan dengan lembaga, mengadakan kegiatan yang mengundang pemerintah terkait, hingga aktif dalam aktivitas audiensi dan lobi secara baik dengan pemerintah (Nasution, 2017).

\section{METODE}

Penelitian ini mengkaji peran dan fungsi public relations di SDIT Darussalam
Selokerto sebagai kasus. Sekolah ini berlokasi di Dusun Selokerto, Sardonoharjo, Ngaglik, Sleman, Yogyakarta dan berada dalam naungan Yayasan Darussalam Selokerto. Dari sisi konteks sekolah ini berada di daerah pedesaan dan sedang dalam proses perintisan, menuju masa pengembangan, sehingga sesuai dengan tujuan penelitian.

$$
\text { Penelitian ini merupakan }
$$

penelitian kualitatif berdasarkan paradigma interpretif. Penelitian kualitatif adalah metode yang digunakan untuk memahami makna yang menyangkut masalah sosial menurut orang atau kelompok tertentu (Creswell, 2016). Jenis penelitian yang digunakan adalah studi kasus (case study). Penelitian kasus menganalisis seseorang atau kelompok secara detail, seperti peristiwa, proses, aktivitas. Kasus dibatasi oleh waktu dan aktivitas (Stake, 1995; Yin, 2009, 2012, dalam Creswell, 2016).

Studi Kasus penelitian ini dilaksanakan di SDIT Darussalam Selokerto yang berlokasi di Dusun Selokerto, Sardonoharjo, Ngaglik, Sleman, Yogyakarta dan berada dalam naungan Yayasan Darussalam Selokerto. Penelitian dilaksanakan selama 6 bulan, pada bulan Desember 2020 hingga bulan Juni 2021. Pengumpulan data di lapangan (field work) dilakukan dengan observasi langsung, pencatatan dan perekaman berbagai informasi dan pengalaman yang relevan, serta wawancara mendalam dengan para informan.

Wawancara mendalam (in depth interviews) dilaksanakan kepada kepala sekolah, guru dan petugas yang menjalankan peran dan fugnsi public relations di sekolah tersebut. Data yang terkumpul selanjutnya dianalisis melalui proses pengkodingan, penyaringan dan seleksi data. Data yang diperoleh dalam penelitian ini dianalisis menggunakan analisis tematik. Untuk memastikan 
kredibilitas data digunakan prosedur triangulasi sumber dan dan referensi.

\section{HASIL DAN PEMBAHASAN Peran dan Fungsi Public relations Sekolah}

SDIT Darussalam Selokerto, sebelumnya di awal berdiri berbentuk Madrasah Ibtida'iyah (MI) Darussalam Selokerto, adalah salah satu unit pendidikan di bawah naungan Yayasan Darussalam Selokerto (YDS). Yayasan ini memiliki visi: "Menjadi Yayasan Islam dengan Amal Usaha Terbaik (Ahsanu Amala)." Sedangkan misinya adalah: "Melaksanakan dakwah Islamiyah untuk mendidik generasi pemakmur masjid". Selain SDIT, YDS juga mengelola pendidikan taman kanak-kanak dan PAUD yaitu: Raudhatul Athfal (RA) Darussalam Selokerto (Afifi \& Susilo, 2014) .

Secara struktural SDIT Darussalam Selokerto tidak memiliki divisi yang menangani secara khusus kegiatan hubungan masyarakat. Menurut Kepala Sekolah Mohammad Hasan, biasaya fungsi tersebut dijalankan langsung oleh kepala sekolah dan beberapa orang guru serta operator sekolah yang terkait dengan teknologi informasi. Berikut ini penjelasan kepala sekolah sebagai informan penelitian ini:

"Secara struktur organisasi, tidak ada divisi public relations atau humas, tetapi secara peran dan fungsi tetap berjalan. Dijalankan langsung oleh kepala sekolah dan guru-guru yang ditunjuk. Biasanya kepala sekolah banyak menjalankan fungsi humas ke luar, berhubungan dengan pemerintah dan masyarakat, sedangkan fungsi internal berupa penyampaian informasi ke wali murid dilaksanakan langsung oleh wali kelas (Mohammad Hasan, wawancara, 5 Februari 2021).

Peran dan fungsi public relations dikoordinasikan langsung oleh kepala sekolah, bahkan untuk aktivitas tertentu langsung ditangani olehnya. Berikut penjelasan, informan yang lain, Muhtarom Ma'arif Suaz, guru sekaligus operator teknologi informasi SDIT Darussalam Selokerto yang juga diberi tugas untuk menjalankan peran dan fungsi public relations:

"Kepala sekolah menjalankan tugas kehumasan yang bersifat eksternal dan juga internal. Eksternal berhubungan dengan dinas pendidikan dan instansi terkait, dan juga dengan masyarakat sekitar. Secara internal kepala sekolah juga banyak berhubungan dengan pengurus Yayasan Darussalam Selokerto. Selain itu menjalankan fungsi pembinaan dan koordinasi dengan para guru dan tenaga kependidikan." (Muhtarom Ma'arif Suaz, Wawancara, 5 Februari 2021).

Selain terkait dengan koordinasi kedinasan maupun kemasyarakatan, penerapan aktivitas lain public relations di sekolah, lebih banyak berhubungan dengan publikasi atau penyebaran informasi mengenai sekolah seperti berbagai program pengembangan atau kegiatan sekolah.

Aktivitas public relations di SDIT Darussalam Selokerto belum berjalan dengan perencanaan yang terprogram dengan sistematis, tetapi lebih pada penyelenggaraan program rutin, seperti pembuatan berbagai perangkat komunikasi pemasaran untuk promosi sekolah. Peran dan fungsi Public relations SDIT Darussalam Selokerto adalah melayani kebutuhan informasi mengenai sekolah ke pihak luar, terutama pemerintah dan masyarakat, serta mengelola media relations dan pemanfaatan media sosial untuk promosi.

Khusus untuk kegiatan promosi sekolah biasanya terdapat tim yang dibentuk oleh kepala sekolah, terdiri dari beberapa orang guru dan tenaga kependidikan. Tim ini menjalankan tugas promosi sekolah untuk penerimaan murid 
baru. Tim ini yang membuat berbagai alat promosi dan bertugas menyebarkan informasi mengenai kegiatan sekolah, baik pra atau pasca kegiatan, melalui media sosial kepada wali murid dan masyarakat.

\section{Internal Relations}

Terkait dengan komunikasi internal sebagai bagian dari public relations manajemen SDIT Darussalam Selokerto mengelola komunikasi dengan pihak Yayasan Darussalam Selokerto (YDS) yang terdiri dari unsur pembina, pengawas dan pengurus. Walaupun dalam praktiknya, secara operasional lebih banyak berkomunikasi dengan pengurus YDS. Koordinasi YDS dengan kepala sekolah SDIT dan RA serta para guru dan karyawan dilaksanakan secara berkala minimal 1 bulan sekali. Dalam rapat tersebut, pihak Yayasan melakukan pembinaan dengan mengingatkan visi misi sekolah, dan berusaha menyelesaikan berbagai persoalan yang muncul. Di saat pandemi Covid-19, koordinasi lebih banyak dilakukan secara online menggunakan zoom meeting.

Peran dan fungsi internal relations dijalankan manajemen sekolah dalam bentuk menjalin hubungan yang baik dengan pihak Yayasan, guru-guru, tenaga kependidikan dan juga orang tua/wali murid. Dalam berbagai forum, kepala sekolah menyampaikan berbagai hal $n$ nilai-nilai, visi-misi, budaya kerja, kinerja.

Koordinasi dan komunikasi internal dilakukan secara formal maupun informal. Secara formal bentuknya dalam forum rapat internal yang diselenggarakan setiap hari Jum'at. Pembinaan oleh pengurus YDS dilaksanakan dalam bentuk Program Pengembangan SDM yang dilaksanakan pada hari Sabtu pekan kedua dan keempat setiap bulan. Biasanya forum tersebut di isi dengan pembinaan keagamaan berupa kajian keIslaman, dan peningkatan kualitas SDM guru dan tenaga kependidikan berupa berupa berbagai pelatihan. Peninjauan kurikulum dan rapat kerja perencanaan dan anggaran dilaksanakan secara rutin setiap tahun.

Mencermati praktik internal relations di sekolah, beberapa jenis media yang sering digunakan adalah: media verbal, media tercetak, media audio visual, $e$-media, dan mix media. Media verbal yang digunakan adalah rapat pekanan (weekly briefing), rapat team (team briefing), dan rapat individu (individual meeting). Media tercetak yang digunakan adalah spanduk, banner, papan pengumuman, poster, pamflet, dan kalender. Sedangkan media audio visual yang digunakan adalah smartphone yang memungkinkan komunikasi dengan fasilitas voice call dan video call. E-media yang digunakan untuk berkomunikasi diantaranya adalah e-mail, WhatsApp Messenger dan Social Media (Facebook, Instagram, YouTube, dan Twitter). Berbagai acara internal yang diselenggarakan sekolah seperti buka puasa bersama, perayaan idul adha bersama, kajian rutin, dan lainnya seringkali menggunakan mix-media dengan memadukan berbagai jenis media komunikasi yang ada.

Secara khusus, penerapan internal relations di SDIT Darussalam Selokerto dilaksanakan dalam bentuk employee relations, dengan melaksanakan empat program yaitu: motivasi kerja berprestasi, pelatihan dan pendidikan lanjutan, penghargaan (reward), dan special event.

Program employee relations yang pertama adalah motivasi kerja berprestasi. Program ini merupakan bentuk komunikasi internal di kalangan guru-guru dan tenaga kependidikan. Berikut penjelasan Kepala Sekolah sebagai informan penelitian ini:

"Motivasi kerja berprestasi dilaksanakan secara rutin oleh pihak yayasan dalam forum pembinaan SDM. Kepala sekolah juga memberikan motivasi kepada para guru dalam rapat rutin. Seain itu bila ada 
event-event perlombaan dari Dinas Pendidikan, SDIT Darussalam Selokerto berusaha mengirimkan perwakilan untuk mengikuti lomba tersebut. (Mohammad Hasan, Wawancara, 5 Februari 2021)

Program employee relations yang kedua adalah program pelatihan dan pendidikan lanjutan. Program pelatihan dan pengembangan SDM dilakukan secara rutin oleh Yayasan Darussalam Selokerto 2 kali setiap bulan, yaitu pada hari Sabtu pekan ke-2 dan ke-4. Bentuknya adalah pembinaan yang terkait keIslaman, berupa kajian keilmuan Islam, dan pengembangan profesionalisme melalui berbagai pelatihan.

Beberapa pelatihan yang pernah dilaksanakan diantaranya adalah: Pelatihan Pengembangan Model Pembelajaran On Line di Masa Pandemi Covid-19, Pelatihan, Pelatihan Komunikasi Pemasaran Sekolah, Pelatihan Pemanfaatan Aplikasi Pembelajaran, Pelatihan Pengelolaan Media Sosial Sekolah, Pelatihan Manajemen Kelas dan lain-lain. Selain dilaksanakan secara internal berbagai pelatihan tersebut juga bersama dengan pihak eksternal dalam bentuk kegiatan Pengabdian Masyarakat, misalnya Pengabdian Masyarakat yang pernah dilaksanakan Program Studi Ilmu Komunikasi UPN "Veteran" Yogyakarta, Program Studi Ilmu Komunikasi Universitas Islam Indonesia, Fakultas Psikologi dan Ilmu Sosial Budaya (FPSB) UII, dan Program Studi Teknik Elektro Universitas Muhammadiyah Yogyakarta. Berbagai pelatihan yang diselenggarakan oleh pihak eksternal juga sering diikuti para guru, seperti kegiatan seminar, workshop, webinar dan lain-lain.

Secara rutin setiap pekan, Yayasan Darussalam Selokerto juga mengadakan Kajian dan Diskusi Pendidikan membahas Kitab Adabul Mufrad karya Imam Bukhari, yang diikuti oleh para guru, tenaga pendidikan, pengurus yayasan dan masyarakat luas. Kajian ini menghadirkan narasumber tetap yaitu: Dr Noor Akhmad Setiawan dari Universitas Gajah Mada yang juga merupakan salah satu Pembina Yayasan Darussalam Selokerto. Sebelum Pandemi Covid-19 kajian rutin tersebut dilaksanakan di masjid sekolah, yaitu Masjid Halimah. Di masa pandemi, kajian tersebut tetap dilaksanakan, tetapi secara online melalui zoom meeting.

Untuk program pendidikan lanjutan dilaksanakan secara personal oleh para guru-guru yang berkeinginan melanjutkan studi lanjut ke jenjang S1 dengan program studi yang dibutuhkan sekolah. Sekolah biasanya memberikan izin dan rekomendasi kepada universitas yang akan dituju. Biasanya guru memilih melanjutkan studi lanjut S1 di Universitas Terbuka dengan program studi Pendidikan Guru Sekolah Dasar (PGSD). Para guru yang studi lanjut sebenarnya telah memiliki ijazah $\mathrm{S}$, tetapi program studinya belum linier dengan bidang pendidikan.

Program employee relations yang ketiga adalah pemberiaan penghargaan (reward). Penghargaan yang diberikan kepada para guru SDIT Darussalam Selokerto berbentuk reward uang transportasi untuk para guru yang hadir sebelum jam 07.00, karena jam operasional sekolah dimulai pada jam 07.0o Berikut penjelasan kepala sekolah terkait program tersebut:

"Program tersebut adalah bentuk penghargaan sekolah kepada guru yang disiplin dan mengawali aktivitasnya di sekolah lebih awal. Di samping penerapan reward kehadiran, sekolah dan yayasan juga merencanakan memberikan reward hafalan Al-Qur'an bagi para guru yang telah menyelesaikan hafalan surah atau juz tertentu. Semangat para guru dalam mengembangkan diri melalui hafalan AlQur'an diharapkan dapat mendukung pembelajaran kepada para murid di sekolah (Mohammad Hasan, Wawancara, 5 Februari 2021). 
Program employee relations yang keempat adalah acara spesial (special event). Special event dilaksanakan secara rutin oleh pihak SDIT Darussalam Selokerto dan Yayasan Darussalam Selokerto. Bentuknya seperti acara buka puasa dan perayaan Idul Adha bersama. Idul Adha dirayakan dengan mengumpulkan hewan Qurban dari pengurus yayasan, guru, orang tua murid atau masyarakat umum, lalu melaksanakan penyembelihan Qurban di sekolah. Saat keadaan normal, acara tersebut dihadiri oleh para guru, murid, serta masyarakat sekitar sekolah. Namun di saat pandemi COVID-19, acara tersebut hanya dihadiri oleh guru dan perwakilan dari komite Sekolah.

$\begin{array}{llr}\text { Berbagai } & \text { kegiatan employee } \\ \text { relations } & \text { dilaksanakan untuk }\end{array}$
kebersamaan diantara para guru, tenaga kependidikan dan juga pengelola Yayasan Darussalam Selokerto. Forum komunikasi baik formal dan informal yang dimiliki tersebut dimanfaatkan untuk membangun arus komunikasi yang sehat dan harmonis, sehingga setiap persoalan dapat segera dicari solusinya. Selain itu setiap program sekolah dapat dikoordinasikan dengan baik untuk mencapai tujuan.

\section{Community Relations}

Komunitas masyarakat di sekitar SDIT Darussalam Selokerto adalah publik eksternal yang sangat penting dalam memberikan dukungan pada keberlangsungan sekolah. Sebagai Lembaga sosial yang melayani pendidikan masyarakat, sekolah sangat memerlukan dukungan masyarakat sekitar untuk mewujudkan pendidikan yang berkualitas. Untuk itu secara intens, sekolah melaksanakan program community relations. Berikut ini penjelasan kepala sekolah sebagai informan penelitian ini:

"Sejauh ini hubungan antara SDIT Darussalam Selokerto dan masyarakat sekitar terbangun sangat baik. Kami terus melakukan koordinasi dengan Ketua RT, Ketua RW, serta tokoh masyarakat setempat, terutama saat wabah Covid-19 melanda. Juga memprioritaskan masyarakat sekitar dalam programprogram sosial yang dilaksanakan sekolah. ( Mohammad Hasan, Wawancara, 5 Februari 2021).

Pihak SDIT Darussalam Selokerto berusaha membangun hubungan baik dengan masyarakat sekitar. Hubungan yang terbangun sudah baik dan tidak ada masalah berarti. Salah satu bentuk nyata dari hubungan baik tersebut disekolahkannya anak-anak oleh para orangtua yang merupakan warga Dusun Selokerto, termasuk salah satunya anak Kepala Dukuh Pedukuhan Selokerto yang menjadi murid sekolah ini.

Secara berkala, pihak sekolah mengumpulkan donasi berbentuk paket sembako dari para orang tua/wali murid untuk disalurkan oleh para murid kepada masyarakat sekitar yang membutuhkan. Kegiatan tersebut dilakukan oleh para murid saat sebelum liburan menjelang bulan ramadhan. Kegiatan ini pun melibatkan Ketua RT sebagai pihak yang memberikan data masyarakat yang diberikan sembako. Kegiatan ini menjadi semacam Corporate Social Responsibility (CSR) sekolah walaupun dalam skala kecil.

Program lain yang pernah diadakan oleh Yayasan Darussalam Selokerto dan sekolah diantaranya adalah pelayanan kesehatan berupa operasi mata katarak gratis bagi masyarakat, bekerjasama dengan RS Dr Sardjito dan Perhimpunan Dokter Spesialis Mata (PERDAMI) dan RS Puri Husada. Selain itu diadakan juga buka bersama yang mengundang masyarakat sekitar, pembagian hewan Qurban dan pengajian umum untuk masyarakat.

Di sisi lain masyarakat Selokerto siap membantu berbagai program sekolah dan ikut menjaga keberlangsungan sekolah, misalnya dengan kegiatan kerja 
bakti bersama membersihkan lingkungan sekolah, menyediakan fasilitas pembelajaran bagi para murid yang ingin belajar tentang peternakan dan pertanian serta berbagai bentuk bantuan lainnya yang secara sukarela diberikan masyarakat kepada sekolah.

Pihak SDIT Darussalam Selokerto juga membangun hubungan baik dengan komunitas tanggap bencana dan sosial keagamaan di kabupaten Slema, diantaranya dengan Tagana (Taruna Tanggap Bencana), dan Peduli Muslim. Hubungan baik dengan Tagana dijalin melalui kelurahan Sardonoharjo. Tagana berkomitmen untuk memberikan edukasi kepada para murid tentang kebencanaan. Tagana bersama Satgas Covid-19 juga melaksanakan program penyemprotan desinfektan untuk mencegah Covid-19 di sekolah. Demikian juga dengan Peduli Muslim yang memberikan bantuan ketika merebaknya Pandemi Covid-19 dengan melakukan penyemprotan disinfektan di lingkungan sekolah dalam kesempatan yang berbeda.

Secara khusus, SDIT Darussalam Selokerto juga memiliki kerjasama yang tertuang dalam Memorandum of Understanding (MoU) dengan Fakultas Psikologi dan Ilmu Sosial Budaya (FPSB) Universitas Islam Indonesia dalam pengembangan pendidikan. Kerjasama dengan perguruan tinggi yang lokasinya relatif dengan lokasi sekolah ini memberikan penguatan pada programprogram sekolah yang terkait dengan pemberdayaan masyarakat dan pengembangan sekolah.

Berbagai program community relations tersebut dilakukan oleh SDIT Darussalam Selokerto dalam menjalin dan menjaga hubungan baik dengan masyarakat sekitar. Kerjasama yang saling menjaga dan saling menguatkan diharapkan memberikan kemanfaatan bagi sekolah dan masyarakat.

\section{Government Relations}

Hubungan baik antara SDIT Darussalam Selokerto dengan instansi pemerintah, terutama Dinas Pendidikan Kabupaten Sleman dan Unit Pelaksana Teknis (UPT) Pelayanan Pendidikan Kecamatan Ngaglik. Pihak SDIT Darussalam Selokerto secara aktif menjalankan berbagai kewajiban administratif dan koordinasi dengan kepada UPT Pelayanan Pendidikan Kecamatan Ngaglik. Berikut ini penjelasan Muhtarom Ma'arif Suaz, guru dan operator teknologi informasi sekolah, yang juga bertugas melaksanakan program government relations:

"SDIT Darussalam Selokerto berusaha aktif melakukan komunikasi dan memperoleh informasi dari instansi terkait, terutama UPT (Unit Pelaksana Teknis). Saat ada instruksi tertentu, pihak sekolah menanggapinya secara aktif. Selain itu, para guru berperan aktif dalam forum Kelompok Kerja Guru (KKG). (Muhtarom Ma'arif Suaz, wawancara, 5 Februari 2021)

Selain itu, SDIT Darussalam Selokerto juga membangun relasi yang baik dengan Dinas Sosial dan Dinas Kesehatan Kabupaten Sleman. Relasi bersama Dinas Sosial terkait dengan kebutuhan pendataan dan pemberian bantuan untuk murid kurang mampu. Sedangkan dengan Dinas Kesehatan berbagai kerjasama dilakukan, diantaranya pelaksanaan program imunisasi untuk para murid sebelum masa Pandemi Covid-19 dan vaksinasi untuk guru di masa pandemi Covid-19.

\section{Media Relations dan Pemanfaatan Sosial Media}

Walaupun belum dilaksanakan secara rutin dan terprogram, media relations sebagai bagian dari kegiatan public relations sekolah dilaksanakan oleh SDIT Darussalam Selokerto. Bentuknya dengan mengirimkan press release 
kegiatan sekolah ke media massa, kunjungan ke kantor redaksi Harian Kedaulatan Rakyat, dan bekerjasama dengan Majalah Pendidikan Fahma untuk peliputan profil sekolah.

Hasil dari aktivitas tersebut berupa dimuatnya berita di media massa tentang SDIT Darussalam Selokerto (waktu itu masih berbentuk Madrasah Ibtidai'iyah Darussalam Selokerto).

Di sisi lain, SDIT Darussalam Selokerto juga memanfaatkan berbagai kanal media sosial untuk mendukung aktivitas public relations sekolah. Beberapa media sosial yang dimiliki oleh SDIT Darussalam Selokerto dan terpantau hingga tanggal 15 November 2021 adalah: Youtube (akun SDIT Darussalam Selokerto) dengan 75 Subscribers dan 57 Video, Facebook (akun SDIT Darussalam Selokerto) dengan 819 Likers, dan 826 followers, serta Instagram (@sdit.darussalamselokerto) dengan 147 Followers, 296 Posts. Selain itu sekolah ini juga memiliki situs resmi dengan alamat website: darussalamselokerto.sch.id.

Untuk pengelolaan media sosial ini, sekolah bersama yayasan membentuk tim khusus promosi yang bertugas membuat berbagai konten promosi, untuk 2 unit sekolah yaitu Raudhatul Athfal (RA) dan SDIT Darussalam Selokerto. Untuk meningkatkan kompetensi anggota tim yang terdiri dari para guru yang memiliki minat dan keterampilan di bidang digital, yayasan dan sekolah beberapa kali mengadakan pelatihan pengelolaan media sosial untuk promosi sekolah.

Berikut ini keterangan yang disampaikan Junaedi, guru SDIT Darussalam Selokerto yang menjadi salah satu anggota tim promosi sekolah:

"Tim promosi sekolah terdiri dari beberapa orang guru yang salah satu tugasnya menjadi admin media sosial. Saya menjadi salah satu admin. Jadi nanti apapun konten informasi dan promosi sekolah akan diposting oleh admin. Kami juga ada website tapi kontennya masih lambat updatenya. Kalau media sosial lain seperti Instagram, facebook, youtube updatenya lebih cepat." (Junaedi, wawancara, 5 Februari 2021)

Melalui berbagai kanal media sosial tersebut sekolah memberikan informasi kepada publik, baik internal maupun eksternal tentang berbagai kegiatan sekolah, termasuk menjadi media promosi sekolah untuk menarik minat orang tua menyekolahkan putra-putrinya di sekolah ini.

\section{Pembahasan}

Hasil penelitian ini menunjukkan bahwa secara struktural tidak ada unit khusus yang menangani public relations di SDIT Darussalam Selokerto. Peran dan fungsi public relations dijalankan oleh kepala sekolah dan beberapa orang guru yang ditunjuk. Keterbatasan SDM dan anggaran sekolah menyebabkan peran dan fungsi public relations tersebut belum ditangani oleh divisi khusus, dan belum dirancang dengan perencanaan yang matang dan implementasi yang rapi. Walaupun demikian sekolah telah menjalankan peran dan fungsi public relations, dalam bentuk aktivitas yang terkait dengan internal relations dan external relations.

Hal tersebut sesuai dengan yang dinyatakan oleh Hugo A De Roode mengenai pertimbangan dalam menempatkan posisi public relations di organisasi, yakni pertimbangan tentang tipe manajemen, harapan dari keberadaan, alasan dibutuhkan, tugas, hubungan dengan organisasi, ketersediaan praktisi, makna keberadaan dan kesadaran public relations pada lingkungan (Rumanti, 2002)

Public relations sekolah bertugas menciptakan, menjaga, dan memperbaiki hubungan baik, menciptakan sikap saling memahami, serta menciptakan 
kepercayaan antara stakeholder, untuk mencapai mutu pendidikan berkualitas.

Menyangkut ketersediaan praktisi, karena SDIT Darussalam Selokerto sedang dalam tahap pengembangan, sumber daya manusia di sekolah masih terbatas. Oleh karena itu, tidak ada pilihan lain bagi pihak sekolah selain memberi amanah pada beberapa guru yang telah mempunyai tugas utama dalam pembelajaran di kelas untuk mengurus public relations sekolah.

Kepala sekolah dan para guru yang masuk dalam tim promosi dan diberi tugas menjalankan peran dan fungsi public relations memahami bahwa tugas mereka yang utama adalah melayani kebutuhan informasi tentang sekolah ke publik seperti menyebarkan informasi terkait pra dan pasca kegiatan sekolah melalui media sosial kepada wali murid dan masyarakat.

Tugas pokok Public Relations relatif telah dijalankan di SDIT Darussalam Selokerto. Lima tugas pokok public relations sehari-hari adalah: (1) menyebarkan informasi (verbal dan nonverbal) pada publik internal dan eksternal; (2) mengawasi, menyimpan, dan mengevaluasi tanggapan masyarakat; (3) menjaga citra lembaga; (4) Bersikap jujur dan terbuka,; dan (5) Melakukan komunikasi dua arah (Rumanti 2002).

Pembuatan kebijakan menjadi ranah kewenangan kepala sekolah dan yayasan. Tim yang menjalankan peran dan tugas public relations lebih banyak menerima masukan dari masyarakat untuk dijadikan bahan dalam pembuatan kebijakan. Berbagai bentuk saran dan kritik dari masyarakat diterima dan diolah untuk kemudian disampaikan kepada kepala sekolah dan yayasan agar ditindaklanjuti untuk dijadikan kebijakan. Misalnya, warga sekitar yang menyarankan agar pembelajaran anak-anak yang difokuskan pada Al-Qur'an lebih ditingkatkan lagi.

Secara terbatas, peran manajerial komunikasi dan teknisi komunikasi public relations dapat ditemui dalam pelaksanaan aktivitas public relations di SDIT Darussalam Selokerto. Walaupun dalam pembuatan perencanaan dan implementasinya belum selengkap konsep perencanaan dan implementasi dalam manajemen public relations.

Cutlip, Center, dan Broom (2005) menjelaskan bahwa public relations tidak dapat dipisahkan dari alur pembuatan program yang berkelanjutan, yakni mencari titik permasalahan (data dan riset), membuat strategi dari hasil analisis, implementasi strategi, dan terakhir evaluasi dari awal hingga akhir sebagai bahan pembuatan strategi selanjutnya.

Hambatan penerapan public
relations yang dihadapi adalah
menyangkut keterbatasan Sumber Daya Manusia (SDM) dan pembiayaan, terutama belum tersedianya praktisi public relations karena memang sekolah sedang dalam tahap pengembangan.

Menyangkut penerapan internal public relations, ditemukan berbagai prinsip penting telah dilaksanakan, diantaranya adalah memberikan arahan untuk berkomunikasi yang baik, responsif, tidak terburu-buru dalam menanggapi pesan dan memiliki kapasitas dalam menyampaikan suatu hal. Walaupun beberapa hambatan ditemui, seperti pemberian respon yang kurang tepat, hingga peserta komunikasi yang kurang responsif di grup media sosial internal.

Internal public relations adalah program komunikasi yang melibatkan publik dalam lembaga yang secara fungsional mempunyai tugas dan hak serta kewajiban tertentu (Sanityastuti, Pratiwi, \& Wijayanti, 2009). Menurut Ardianto, internal relations berfungsi mengarahkan publik internal dalam menjaga reputasi dan citra baik lembaga di mata publik, salah satu penerapannya adalah dengan menjaga budaya lembaga. Budaya lembaga, sense of belonging (rasa 
memiliki) dan rasa tanggung jawab dapat tumbuh di ranah internal (Antono, 2018).

Sekolah juga telah melakukan berbagai hal tersebut dengan relatif baik. Walaupun demikian, berbagai hambatan penerapan employee relations juga ditemukan terutama terkait keterbatasan dana dalam mendanai program studi lanjutan para guru maupun peningkatan kesejahteraan mereka secara umum.

Berbagai program community relations yang dijalankan pihak sekolah dengan menjalin hubungan yang baik dengan masyarakat sekitar, tokoh masyarakat dan agama, hingga komunitaskomunitas penting seperti komunitas tanggap bencana telah berkontribusi pada harmonisnya hubungan baik sekolah dengan masyarakat sekitar.

Penerapan aktivitas government relations SDIT Darussalam Selokerto juga menjadi bagian penting dalam manajemen publik eksternal. Government relations adalah turunan external public relations yang berfokus pada hubungan lembaga dengan pemerintah, regulator, legislatif, dan aparat (Suwatno, 2018). Dalam skala yang lebih kecil dan terbatas, SDIT Darussalam Selokerto telah menjalin hubungan baik dengan instansi pemerintah terutama dengan Dinas Pendidikan melalui UPT Pelayanan Pendidikan Kecamatan, Dinas Sosial dan Dinas Kesehatan.

Media relations yang dilaksanakan juga bermanfaat untuk meningkatkan citra sekolah, hanya saja pelaksanaannya masih sangat terbatas, dan hanya dilaksanakan pada awal sekolah berdiri saja. Belum ada keberlanjutan program media relations dari berbagai aktivitas sekolah yang sebenarnya menarik untuk diliput media massa. Pemanfaatan media sosial untuk kegiatan public relations juga dimulai, terbukti dengan dimilikinya website, akun youtube, instagram dan facebook yang digunakan untuk promosi sekolah. Hanya saja, pengelolaannya yang perlu ditingkatkan lagi, terutama dalam konsistensi mengmperbaharui konten.

\section{KESIMPULAN}

Secara struktural SDIT Darussalam Selokerto belum memiliki divisi public relations tetap peran dan fungsi telah terlaksana melalui kerja kepala sekolah dan tim promosi sekolah yang terdiri dari para guru yang ditunjuk. Kepala sekolah lebih banyak menjalankan tugas untuk menjalin komunikasi dengan publik eksternal seperti pemerintah, masyarakat, dan media, selain tetap berkoordinasi secara internal dengan pihak yayasan dan juga para guru serta tenaga kependidikan.

Peran dan fungsi public relations sekolah dilaksanakan oleh kepala sekolah bersama beberapa orang guru yang tergabung dalam promosi sekolah dengan menjalankan kegiatan yang dapat dikategorikan sebagai aktivitas employee relations, community relations, government relations, media relations dan pemanfaatan media sosial untuk promosi sekolah.

Belum dirancangnya perencanaan aktivitas public relations secara terstruktur dan sistematis menjadi kendala tersendiri dalam implementasi peran dan fungsi tersebut. Alur manajemen public relations ideal yang dimulai dengan tahap perencanaan dengan dukungan data dan pengenalan masalah yang memadai, implementasi, serta evaluasi belum terlaksana dengan baik. Kendala yang dihadapi juga terkait dengan terbatasnya SDM dan ketersediaan anggaran yang mendukung berbagai program public relations sekolah.

Walaupun masih menghadapi banyak keterbatasan, SDIT Darussalam Selokerto telah mengembangkan peran dan fungsi public relations sekolah sesuai dengan kemampuan dan kondisi yang ada. Berbagai aktivitas yang telah dilaksanakan sangat berpotensi dikembangkan lebih baik lagi di masa mendatang. 
Pengembangan kompetensi SDM terutama terkait dengan public relations telah dilaksanakan pihak sekolah dan yayasan melalui berbagai kegiatan pelatihan dan pengabdian masyarakat yang dilakukan perguruan tinggi di sekolah tersebut. Hal ini menjadi modal penting untuk pengembangan peran dan fungsi public relations sekolah dan harapannya memberi dampak yang positif pada pengembangan sekolah di masa depan.

Peneliti memberikan rekomendasi kepada sekolah untuk mengembangkan perencanaan aktivitas public relations secara lebih sistematis berbasis data dan analisis persoalan yang dihadapi dan mengoptimalkan potensi kerjasama sekolah dengan pihak eksternal serta memfasilitasi aktivitas public relations sekolah secara lebih baik. Pengembangan kompetensi SDM khususnya tim promosi yang bertugas menjalankan peran dan fungsi public relations diharapkan juga terus ditingkatkan, melalui berbagai bentuk pelatihan.

Peneliti selanjutnya diharapkan dapat mengembangkan topik-topik penelitian dengan tema public relations lembaga pendidikan dalam berbagai aspek dan persoalannya, untuk memperkaya khazanah kajian public relations dalam bidang ilmu komunikasi.

\section{DAFTAR PUSTAKA}

Afifi, S. \& Susilo, M.E. (2014). Pengembangan Komunikasi Pemasaran Sekolah. Jurnal Ilmu Komunikasi, Volume 13, Nomor 3, September - Desember 2014. 277286.

Afifi, S. \& Hariyanti, P. (2021). The Relationship Marketing Communication Strategy During the Covid-19 Pandemic : A Case Study of Islamic Schools in Yogyakarta. 596(Jcc), 235-240. https://doi.org/10.2991/assehr.k.211 121.056

Antono, Fransisca. (2018). Strategi Internal Relations Untuk Meningkatkan Motivasi Kerja : Studi Kasus Terhadap Kegiatan Internal Relations PT Japfa Comfeed Indonesia Unit Tangerang. 7 April 2020. http://kc.umn.ac.id/id/eprint/5882
Choerunnisa \& Yuniarti. (2015). Komunikasi Internal Humas PT Pertamina (Persero) Dalam Media Energia Weekly. 14 Januari 2020. http://jurnal.unismabekasi.ac.id/in dex.php/makna/article/download/8 $\underline{10 / 695}$

Creswell, John. (2016). Research Design: Pendekatan Metode Kualitatif, Kuantitatif, dan Campuran (Edisi ke-4). Yogyakarta : Pustaka Pelajar.

Cutlip, Scott., Center, Allen., \& Broom, Glen. (2005). Effective Public Relations : Merancang dan Melaksanakan Kegiatan Kehumasan Dengan Sukses (Edisi ke-8). Jakarta : PT. Indeks Kelompok Gramedia.

Cutlip, Scott., Center, Allen., \& Broom, Glen. (2007). Effective Public Relations (Edisi ke-9). Jakarta: Kencana.

Cahyaningrum, Sri. (2018). Strategi Public Relation Dalam Mengembangkan Citra Lembaga Madrasah di MAN 2 Ponorogo. 18 Januari 2021. http://etheses.iainponorogo.ac.id/3 938/1/SKRIPSI\%2OAPLUT.pdf 
Fitri, Ana Rose. (2018). Cyber Public relations Dunia Pendidikan (Studi Implementasi Cyber Public relations di SMA Muhammadiyah 2 Surabaya). 8 Februari 2021. http://digilib.uinsby.ac.id/25072/1/ Ana\%20Rose\%20Fitri_B76214058. pdf

Hartini, Tin. (2016). Strategi Community Relations Dalam Lembaga Pendidikan. 26 Januari 2021. http://jurnal.unismabekasi.ac.id/in dex.php/makna/article/download/7 96/680

Hendrix, Jerry \& Hayes, Darrell. (2010). Public relations Cases. Boston : Wadsworth Cengage Learninng.

Jambi.tribunnews.com. (2020). BREAKING NEWS 'Tak Cocok' dengan Kepala Sekolah, Guru SD Sarolangun Mogok Ngajar. 29 Juni 2020.

https://jambi.tribunnews.com/2020 /o2/17/tak-cocok-dengan-kepalasekolah-guru-sd-di-sarolangunmogok-ngajar

Junaedi. (2018). Kesal Guru Mogok Mengajar, Ratusan Orang Tua Murid Demo ke Sekolah. 26 Januari 2021.

https://regional.kompas.com/read/ 2018/o8/24/12450091/kesal-gurumogok-mengajar-ratusan-orangtuamurid-demo-ke-sekolah?page=all

Kasali, Rhenald. (1994). Manajemen Public Relations: Konsep dan Aplikasinya di Indonesia. Jakarta: Pustaka Utama Grafiti.

Kompas.com. (2018). Guru Mogok Mengajar, Ribuan Pelajar SMA Dipulangkan. 15 Desember 2020. https://regional.kompas.com/read/ 2018/10/17/10071391/guru-mogokmengajar-ribuan-pelajar-sma-smk$\underline{\text { di-mimika-dipulangkan?page }=\text { all }}$
Mardiansyah, Ferbi. (2011). Strategi Employee Relations Di SMA Negeri 1 Kota Serang (Studi Kasus Korupsi Dana Sumbangan Pendidikan Kepala Sekolah di SMA Negeri 1 Kota Serang). 8 Februari 2021. http://eprints.untirta.ac.id/151/1/S KRIPSI\%20KOM\%20Ferbi\%20Mar diansyah.pdf

Mayasari, Silvina \& Angguntiara, Chitra. (2018). Strategi Humas PT. Pelayaran Nasional (Persero) Indonesia Dalam Membuat Tabloid Sebagai Media Informasi Publik Internal. 28 Januari 2021. https://ejournal.bsi.ac.id/ejurnal/in dex.php/jkom/article/view/3405

Mulyana, Deddy. (2010). Ilmu Komunikasi Suatu Pengantar (Edisi ke-14). Bandung : PT. Remaja Rosdakarya.

Mulyono, Yakub. (2019). Tuntut Kasek Mundur, Guru Mts di Jember Mogok Mengajar. 15 Desember 2020.

https://news.detik.com/berita-jawatimur/d-4406603/tuntut-kasekmundur-guru-mts-di-jembermogokmengajar?_ga $=2.93885405 .179503$ 8163.1608024922890071539.1607928104

Nafi'ah, Elmi Hidayatin. (2018). Strategi Public Relations SDIT Darul Falah Sukorejo Ponorogo Dalam Membangun Citra Lembaga Terhadap Khalayak Eksternal. 26 Januari 2021. http://etheses.iainponorogo.ac.id/3 580/1/elmi\%2opdf\%2ojadi.pdf

Nasution, Vinny Fhiadina. (2017). Analisis Implementasi Community dan Government Relations Di Kebun Sei-Kencana PTPN V (Persero) Pekanbaru. 9 Maret 2021. https://dspace.uii.ac.id/handle/123 $456789 / 5578$ 
Rumanti, Sr. Maria Assumpta. (2002). Dasar-Dasar Public Relations: Teori dan Praktik. Jakarta : PT. Grasindo.

Sanistyatuti, Marfuah., Pratiwi, Fatma., \& Wijayanti, Yani. (2009). Dasardasar Public Relations. Yogyakarta : Teras.

Siwala, Nurul. (2017). Pelaksanaan Fungsi Internal \& Eksternal Public relations Hotel Santika Premiere Dyandra Medan. 23 Januari 2021. http://repository.uma.ac.id/bitstrea $\mathrm{m} / 123456789 / 8486 / 1 / 138530026 . p$ df

Suwatno. (2018). Pengantar Public relations Kontemporer. Bandung: PT. Remaja Rosdakarya.

Utomo, H.J.N \& Afifi, S. (2004). Strategi Komunikasi Pemasaran Usaha Kecil Menengah (UKM) Di Kabupaten
Bantul dan Kulon Progo Yogyakarta. Jurnal Ilmu Komunikasi (Vol. 2, Issue 2). Mei-Agustus 2004.

Wasesa, Silih, (2006). Strategi Public Relations. 22 April 2020. https://books.google.com/books?hl =en\&lr=\&id =8E2DC3sva3EC\&oi $=\mathrm{fn}$ d\&pg $=$ PR17\&dq $=$ strategi + internal $+\mathrm{r}$ elations\&ots $=$ ZVXontM6en\&sig $=\mathrm{dks}$ 9XjmZHW5 dI $5 \mathrm{c}_{3} \mathrm{WtX}_{5} \mathrm{TSh}_{4} \mathrm{lFo}_{\mathrm{F}}$

Yudarwati, G. Arum. (2004). Community Relations: Bentuk Tanggung Jawab Sosial Organisasi. 8 Maret 2021. https://ojs.uajy.ac.id/index.php/jik/ article/download/164/250

Ziehad, Bina. (2019). Program Employee Relations Dalam Membangun Kinerja Karyawan (Analisis Deskriptif PT Len Industri). http://digilib.uinsgd.ac.id/28116/ 